\title{
PREKID KONTINUITETA RADNJE TRAJNOG KAZNENOG DJELA POVREDE DUŽNOSTI UZDRŽAVANJA
}

\author{
UDK: 343.62 \\ DOI:10.31141/zrpfs.2021.58.141.763 \\ Pregledni rad \\ Primljeno: 20. prosinca 2021.
}

Karakteristično protupravno stanje hotimičnog izbjegavanja obveze uzdržavanja druge osobe koje svojom radnjom stvori počinitelj kaznenog djela, može opstojati ovisno ili neovisno o njegovoj volji. Budući da je povreda dužnosti uzdržavanja trajno kazneno djelo, nameće se pitanje prekida li pravomoćna sudska odluka kaznenog suda kontinuitet neprava i je li moguće okorjelom povratniku ponovno suditi, bez povrede načela ne bis in idem.

U radu je korištena metoda analize, deskriptivna za obilježja djela, a eksplikativna za poseban osvrt na ličnost počinitelja i utvrđivanje oblika privremenog prestanka neprava na strani počinitelja. Statističkom metodom u kombinaciji s metodom uzorka provedeno je specifično istraživanje konkretnih predmeta na usustavljenom uzorku punoljetnih počinitelja kaznenog djela nedozvoljene trgovine na području Republike Hrvatske.

Rezultati istraživanja pokazuju da svršetak radnje uskrate izdvajanja sredstava za skrb o drugoj osobi različitoj od počinitelja kaznenog djela ne ovisi uvijek o njegovim postupcima, da osuda ne smije predstavljati temelj ili podstrek za daljnje kršenje obveze i da pravomoćna sudska presuda mora biti osnova zaključka da je dovršena radnja trajnog kaznenog djela povrede dužnosti uzdržavanja.

Zaključno se utvrđuje da osuda za trajno kazneno djelo povrede dužnosti uzdržavanja ne uključuje i daljnje održavanje protupravnog stanja prouzročenog propuštanjem zakonske obveze počinitelja da pribavlja nužna sredstva za život osobe o kojoj je dužan skrbiti.

Ključne riječi: pravo na uzdržavanje, povreda dužnosti uzdržavanja, trajno kazneno djelo, radnja, protupravno stanje

\section{UVODNE NAPOMENE}

Do sada nije istraženo na koje sve načine dolazi do prekida kontinuiteta radnje kaznenog djela povrede dužnosti uzdržavanja, s obzirom na to da se radi o trajnom kaznenom djelu te koliki se postotak odraslih počinitelja poziva na presuđenu stvar nakon ranije osude.

1 Bruno Moslavac, zamjenik općinskog državnog odvjetnika u Općinskom državnom odvjetništvu u Virovitici, Kazneni odjel. Ovaj rad izrađen je sukladno odredbi čl. 101. st. 1. Zakona o državnom odvjetništvu (NN 67/18). Svi stavovi i mišljenja izneseni u radu isključivo su stavovi i mišljenja autora i ni na koji način ne predstavljaju stavove i mišljenja institucije u kojoj je autor zaposlen niti to jesu. 
Cilj provedenog istraživanja jest utvrditi profil punoljetnih počinitelja koji krše obvezu davanja uzdržavanja, u koju svrhu je kombinirana statistička metoda s metodom uzorka, dok je specifičan cilj utvrditi na koje sve načine dolazi do prekida kontinuiteta radnje kaznenog djela povrede dužnosti uzdržavanja, s obzirom da se radi o trajnom kaznenom djelu.

Hipoteza br. 1: Prestanak protupravnog stanja ne ovisi u svakom slučaju o radnjama ili propuštanju počinitelja koji se ne pridržava zakonske dužnosti.

Hipoteza br. 2: Pravomoćna sudska osuda zbog povrede dužnosti uzdržavanja prekida kontinuitet radnje kaznenog djela.

Deskriptivnom analizom sudskih presuda i statističkom metodom prikupljeni su podaci o ključnim elementima bića kaznenog djela povrede dužnosti uzdržavanja, o profilu punoljetnih počinitelja te žrtvama kaznenog djela, dok su eksplikativnom analizom pojašnjene pobude nepridržavanja dužnosti uzdržavanja i pojavni oblici prestanka protupravnog stanja.

Istraživanjem je obuhvaćen sistematski uzorak od 53 drugostupanjske presude svih žalbenih sudova na području Republike Hrvatske, u razdoblju od 1. siječnja 2015. do 31. svibnja 2020., ${ }^{2}$ uz sigurnost < 0,95 i apsolutnu granicu pogreške (+/- 5 $\%)$.

Proučavanu jedinicu predstavljaju pojedinačni počinitelji koji dolaze iz različitih društvenih sredina, radnopravnoga statusa, imaju različitu kriminalnu prošlost i motive za izbjegavanje obveze uzdržavanja. Analizom prikupljenih podataka opisana je ličnost karakterističnog počinitelja i utvrđeni razlozi zbog kojih dolazi do prestanka kršenja obveze uzdržavanja.

\section{ZAKONSKA OBVEZA UZDRŽAVANJA}

Uzdržavanje je (zakonsko) pravo propisano odredbom čl. 281. Obiteljskog zakona. $^{3}$ Ujedno predstavlja i obvezu ${ }^{4}$ istih titulara, pojedinačno određenih u navedenoj zakonskoj odredbi, kao roditelja i djece, bračnih i izvanbračnih drugova, srodnika u ravnoj lozi te pastorka i maćehe i očuha. Slučajevi obveze davanja uzdržavanja i konzumiranja prava na uzdržavanje propisani su OZ-om, uz uvažavanje načela razmjernosti, da ovlaštenici i obveznici međusobnom uzdržavanju pridonose prema svojim mogućnostima i potrebama uzdržavane osobe (čl. 282. OZ-a). Prema ranije važećim propisima, uzimajući u obzir činjenicu da današnjim institutom posvojenja nastaje trajni odnos roditelja i djece (čl. 180. st. 1. OZ-a) te

\footnotetext{
2 Zbog malog uzorka drugostupanjskih presuda tijekom 2020., iste su prikazane s podacima za 2019., dodatno znajući da je riječ o predmetima iz ranijih godina promatranog razdoblja.

3 NN 103/15, 98/19 (dalje u tekstu: OZ).

4 "Zakonska je obveza roditelja uzdržavati dijete koje mu nije povjereno na odgoj i čuvanje. Riječ je o obvezi roditelja financijske naravi, doprinositi za osnovne egzistencijalne potrebe djeteta, koji s tim roditeljem ne živi, a koje potrebe su stalne i dnevne. Svaki roditelj u izvršavanju ove obveze mora uložiti maksimalne napore, biti savjestan i redovit" (ŽsRi broj: Kžzd-24/2016-4 od 30. studenoga 2016.).
} 
neraskidiv odnos srodstva i sva prava i dužnosti koje iz toga proizlaze (čl. 197. st. 1. OZ-a), bilo je moguće odrediti doprinos za uzdržavanje, za slučaj prestanka posvojenja (usvojenja). Odluku je donosio "organ starateljstva", kao izuzetak od pravila da odluku o uzdržavanju donosi uvijek sud, u rješenju kojim potvrđuje ili izriče prestanak posvojenja. Doprinos za uzdržavanje određivan je ako su za to postojali opravdani razlozi, uzimajući u obzir razlog za prestanak posvojenja te novonastalu situaciju bivšeg posvojenika i posvojitelja. ${ }^{5}$ "Za pravilan razvoj i odgoj djeteta vrlo je važno da ono ima barem minimalnu ekonomsku osnovu koja je za to potrebna. Regulirajući prava i dužnosti roditelja i djece, zakonodavci su već od najranijih vremena predviđali pravnu obvezu roditelja da uzdržavaju svoju djecu. Na žalost, nisu rijetki slučajevi kad najčešće jedan, rjeđe oba roditelja nastoje izbjeći tu obvezu."6 Počinitelj koji namjerno izbjegava karakterističnu obvezu skrbi o drugome dospijeva pod lupu kaznenopravne represije.

\section{OSNOVNE ZNAČAJKE KAZNENOG DJELA POVREDE DUŽNOSTI UZDRŽAVANJA}

"Građanskopravna obveza uzdržavanja prerasta u kazneno djelo u slučaju kad počinitelj aktivnim postupanjem ili propuštanjem svjesno nastoji trajno ili privremeno onemogućiti ostvarivanje dužnog uzdržavanja, a iz njegova je ponašanja očito da on tu svoju namjeru može objektivno postići. Oštećenik nije dužan višekratnim ovršnim postupcima dokazivati postojanje počiniteljeve kriminalne namjere. ${ }^{17}$ Stilizacija zakonskog opisa djela pokazuje da zakonska obveza, odnosno pravo na uzdržavanje mora biti regulirano ovršnom ${ }^{8}$ ispravom. Krug počinitelja je određen: samo osobe koje su po zakonu dužne uzdržavati drugu osobu, stoga je riječ o delictum proprium. Ovo je trajno kazneno djelo jer se njime krši obveza na činjenje pa djelo traje sve dok osoba ne počne ispunjavati svoju obvezu uzdržavanja. Također je to pravo kazneno djelo nečinjenja, ${ }^{10}$ jer se sastoji u propuštanju obveze na uzdržavanje. U svakom slučaju, riječ je o namjernom kaznenom djelu, bilo da

5 Prokop, Ana, Porodično pravo: usvojenje, Informator, Zagreb, 1970., str. 128.

6 Singer, Mladen, Mikšaj-Todorović, Ljiljana, Poldrugač, Zdravka, Kriminalitet na štetu maloljetnika, Školska knjiga, Zagreb, 1989., str. 127.

7 Bačić, Franjo, Pavlović, Šime, Komentar Kaznenog zakona, Organizator, Zagreb, 2004., str. 739.

8 "Ovršnost isprave kojom je utvrđena obveza uzdržavanja odlučna je činjenica budući da prema zakonskom tekstu kazneno djelo povrede dužnosti uzdržavanja iz čl. 172. st. 2. i 1. KZ/11 čini onaj tko ne uzdržava dijete koje je po zakonu dužan uzdržavati i to na način, u visini i u rokovima određenim ovršnom ispravom. Tek kada isprava kojom je određena obveza uzdržavanja postane ovršna, onaj tko od tada ne postupa po istoj ulazi u kaznenu zonu, a sve do datuma ovršnosti, neovisno o tome što je obveza uzdržavanja utvrđena i za razdoblje prije ovršnosti isprave, ista potpada pod građansko-pravnu sferu" (ŽsVž broj: 22 Kžzd-14/18-4 od 9. svibnja 2018.).

9 Postoje i drugi načini ili oblici postanka obveze, posljedično i prava (za uzdržavanu osobu) na uzdržavanje, poput ugovornog, dogovornog, odlukom tijela javne ili državne (sudbene) vlasti i dr.

10 Prava kaznena djela nečinjenja jesu ona koja se mogu počiniti samo nečinjenjem. Novoselec, Petar, Martinović, Igor, Komentar Kaznenog zakona, I. knjiga: opći dio, Narodne novine, Zagreb, 2019., str. 108. 
počinitelj postupa s izravnom, ${ }^{11}$ bilo s neizravnom namjerom. ${ }^{12}$ Namjera (i) kod kaznenih djela nečinjenja podrazumijeva svijest počinitelja o djelu, što znači da mora biti svjestan postojanja situacije koja zahtijeva činjenje, kao i vlastite mogućnosti poduzimanja radnje te mora htjeti ostvarenje bića kaznenog djela ili na njega barem pristati. ${ }^{13}$ Okolnost da počinitelj ne viđa vlastito dijete ukazuje upravo na namjeru da ne plaća uzdržavanje i nikako ne opravdava obranu da je mislio da zbog toga nije dužan plaćati alimentaciju. ${ }^{14}$ "Potrebno je da optuženik, koji je otac još troje djece, uzdržava i dijete s kojim ne živi, bez obzira što on smatra da dijete nije njegovo, jer je pravomoćnom presudom suda utvrđen kao otac djeteta." ${ }^{15}$ Prava kaznena djela nečinjenja obično ne sadrže posljedicu; dovoljno je da počinitelj ne poduzme aktivnu radnju koju je dužan poduzeti, neovisno o tome je li njegovo nečinjenje rezultiralo kakvom daljnjom posljedicom. ${ }^{16}$ Zaštitni je objekt socijalna sigurnost uzdržavane osobe.

\section{SPOSOBNOST POČINITELJA DA PODUZME RADNJU}

Jedno od otvorenih pitanja kod kaznenog djela povrede dužnosti uzdržavanja, koje se proteže kroz sudske odluke i praksu, jest ono o sposobnosti počinitelja da izvrši obvezu uzdržavanja. Naime, sva kaznena djela nečinjenja, u koju skupinu spada i proučavano kazneno djelo iz čl. 172. Kaznenog zakona (NN 125/11, 144/12, 56/15, 61/15, 107/17, 118/18, 126/19; dalje u tekstu: KZ), moguća su samo ako je počinitelj tempore criminis bio sposoban poduzeti radnju. ${ }^{17}$ Po pitanju davanja ${ }^{18}$ uzdržavanja ili, kolokvijalno, alimentacije, ${ }^{19}$ osnovica za izvođenje zaključka suda o sposobnosti neplatiše da dospije pod lupu kaznene represije jest okolnost je li radno

11 ŽsZg broj: Kžzd-107/2018-5 od 22. siječnja 2019., ŽsSt broj: Kžzd-4/2019-5 od 5. veljače 2019.

12 Dragičević Prtenjača, Marta, "Kaznena djela protiv braka, obitelji i djece", u: Cvitanović, Leo, Derenčinović, Davor, Turković, Ksenija, Munivrana Vajda, Maja, Dragičević Prtenjača, Marta, Maršavelski, Aleksandar, Roksandić Vidlička, Sunčana, Kazneno pravo: posebni dio, Pravni fakultet Sveučilišta u Zagrebu, Zagreb, 2018., str. 237-241.

13 Novoselec-Martinović, op. cit. (bilj. 6), str. 115. Isto: ŽsVž broj: 5 Kžzd-65/16-5 od 12. prosinca 2017.

14 ŽsSB broj: 21 Kžzd-10/2017-4 od 29. siječnja 2018.

15 ŽsZg broj: Kžzd-102/18-4 od 3. siječnja 2019.

16 Novoselec-Martinović, op. cit. (bilj. 6), str. 109.

17 Ibid, str. 106.

18 Posebnim propisom zakonske snage uzdržavanje u novcu ("plaćanje") propisano je kao obvezatno jedino za dijete kao uzdržavanu osobu (čl. 309. OZ-a).

19 Ranije je odnosno kazneno djelo bilo poznato pod nazivom neplaćanje alimentacije. Bačić, Franjo, Šeparović, Zvonimir, Krivično pravo: posebni dio, Peto, izmijenjeno i dopunjeno izdanje, Informator, Zagreb, 1997., str. 152. 
sposoban..$^{20}$ Izreke sudskih presuda i opis činjeničnog stanja po pitanju počinjenja predmetnog kaznenog djela nerijetko sadrže upravo navod o radnoj sposobnosti. ${ }^{21}$ Činjenica da u vrijeme kada je počinitelj bio dužan izvršiti zakonsku obvezu uzdržavanja nije formalno bio zaposlen, u posljednje vrijeme u sudskoj praksi nije valorizirana i nije utjecala na opstojnost zaključka o neizvršavanju obveze. ${ }^{22}$ "Iznenadna bolest na koju se sada poziva optuženik, nije opravdani razlog zbog kojega nije mogao izvršiti naloženu obvezu, obzirom da je na bolničkom liječenju bio manje od dva mjeseca, a otpušten je na kućnu njegu dobrog općeg stanja, uz preporuku izbjegavanja težih fizičkih napora."23

\subsection{Neformalan rad kao temelj obveze uzdržavanja}

Ostvarivanje prihoda radom "na crno" također se vrednuje kao zarađivanje te posljedično direktno utječe na (ne)izvršavanje obveze uzdržavanja. ${ }^{24}$ "Optuženik je u inkriminiranom razdoblju obavljao različite poslove u različitim tvrtkama te kontinuirano bio u radnom odnosu, izuzev kraćeg perioda od par mjeseci, što znači da je bio u mogućnosti doprinositi uzdržavanju svoje kćeri."25 "Osiguran smještaj kod roditelja, zasigurno je umanjio rashode optuženika, a kako je on osoba srednje životne dobi, sposobna za rad, po zanimanju konobar, mogao je obavljati i dodatne poslove te tako u cijelosti ispuniti dugovano uzdržavanje prema svojoj djeci." 26 "Podnošenje zahtjeva za ostvarenje prava na mirovinu ne isključuje obvezu plaćanja uzdržavanja. Stoga nije jasno po kojoj to osnovi i temeljem čega okrivljenik smatra da u inkriminirano vrijeme nije smio raditi, pa samim time nije mogao plaćati svoju obvezu s naslova uzdržavanja." 27

20 Radno sposoban roditelj ne može se osloboditi dužnosti uzdržavanja maloljetnog djeteta (čl. 288. st. 1. OZ-a). "Sud je okrivljenici uzeo u obzir da je radno sposobna osoba u dobi od 40 godina i da je izostalo veće osobno angažiranje okrivljenice na osiguranju novčanih sredstava za uzdržavanje oštećenika te da nije osnovano pozivanje okrivljenice na malu životnu dob kćerke, jer da i sama naglašava da će se o istoj za vrijeme izdržavanja zatvorske kazne brinuti njezina majka, a što znači da je to mogla učiniti i kada bi ona bila radno angažirana uključujući i odlazak na rad na nadnice" (ŽsSt broj: Kžzd-73/2018-5 od 4. rujna 2018.). "Okrivljenik je u mogućnosti plaćati puni novčani iznos za uzdržavanje svoje kćerke jer je radno sposobna osoba u dobi od 38 godina, zaposlen je, a može se i dodatno zaposliti i na taj način steći primanja te je kreditna obveza za kupnju kuće nastala kad je okrivljeniku sudskom odlukom već bila utvrđena visina iznosa koji treba doprinositi za uzdržavanje" (ŽsZg broj: Kžzd-107/2018-5 od 22. siječnja 2019.). Isto: ŽsBj broj: Kžzd-26/2018-4 od 22. studenoga 2018., ŽsBj broj: Kžzd-31/2019-4 od 14. studenoga 2019.

${ }^{21}$ OsVt broj: 2 Kzd-12/2019-3 od 28. svibnja 2019.; OsVt broj: 6 Kzd-5/2019-4 od 27. veljače 2019.; OsVt broj: 6 K-11/2018-2 od 12. siječnja 2018., OsŠi broj: Kzd-34/2017-17 od 25. siječnja 2019.

22 ŽsSt broj: Kžzd-80/16 od 1. prosinca 2016.; Žš̌i broj: Kžzd-18/2018-4 od 12. rujna 2019.

23 ŽsBj broj: Kžzd-1/2019-4 od 7. veljače 2019.

24 ŽsŠi broj: Kžzd-23/18-4 od 15. studenoga 2018., ŽsVu broj: 1 Kžzd-11/2018-6 od 28. lipnja 2016.

25 ŽsOs broj: Kžzd-38/2019-4 od 6. lipnja 2019.

26 ŽsSt broj: Kžzd-9/2020-5 od 5. veljače 2020.

27 ŽsZg broj: 7 Kž-166/2019-8 od 26. veljače 2019. 


\subsection{Izbjegavanja dužnosti uzdržavanja}

Ranije je djelo bilo počinjeno samo ako je počinitelj izbjegavao ${ }^{28}$ davanje uzdržavanja. Nije bilo dovoljno što određena osoba ne daje dužno uzdržavanje, nego je počinitelj morao aktivnim postupanjem ili propuštanjem svjesno htjeti da trajno ili privremeno onemogući ostvarivanje dužnog uzdržavanja, a poduzeto činjenje ili propuštanje bilo je takve prirode da se njime navedena namjera mogla objektivno postići. ${ }^{29}$ Sporno je ostalo je li za dokaz postojanja "izbjegavanja" potrebna prethodna neuspjela sudska ovrha, premda kazneno djelo postoji neovisno o tome je li ispunjenje obveze zatraženo u ovršnom postupku. ${ }^{30}$

\subsection{Nepopustljivost počinitelja}

Ustrajnost u neispunjavanju zakonske obveze dužnosti uzdržavanja sud vrednuje kao otegotnu okolnost počinitelju. ${ }^{31}$ Sud cijeni u obzir da je osuđenica sposobna davati uzdržavanje jer "prima porodiljnu naknadu, njezin izvanbračni suprug prima mirovinu te uz to ostvaruju prihode od poljoprivrede i izrade ogrjevnih drva koje prodaju", tako da doista nema opravdanja za neispunjavanje obveze. ${ }^{32}$ Obveza uzdržavanja djeteta ima prioritet u odnosu na sve druge obveze i probitke počinitelja, ${ }^{33}$ tako da odsutnost stalnog zaposlenja, odnosno povremeni rad, kao i činjenica sklapanja novog braka u kojem je rođeno još jedno dijete, ne utječu na

28 "Čl. 172. stavak 1. je preformuliran kako bi se pojednostavili sudski postupci koji sada traju dugo jer se mnogo vremena troši na dokazivanje izbjegavanja zaposlenja i ostalih okolnosti koje su se navodile u članku 209. stavak 1. KZ/97. Stoga radnje koje imaju za cilj izbjegavanje plaćanja alimentacije više nisu dio bića kaznenog djela, već je dovoljno da počinitelj ne podmiruje uzdržavanje za osobu koju je po zakonu dužan uzdržavati i to na način, u visini i u rokovima određenim ovršnom ispravom. Time je ovo kazneno djelo postalo pravo kazneno djelo nečinjenja kao u slovenskom Kaznenom zakonu (članak 194. stavak 1.), crnogorskom Kaznenom zakonu (članak 221. stavak 1.) te švicarskom Kaznenom zakonu (članak 217.). Izmijenjen je i pravni temelj za plaćanje alimentacije pa to više nije samo ovršna odluka ili sudska nagodba, već svaka ovršna isprava. Time se želi obuhvatiti i, primjerice, nagodba pred Centrom za socijalnu skrb ili javnim bilježnikom." Konačni prijedlog Kaznenog zakona, Zagreb, listopad 2011., str. 202. Isto: Horvatić, Željko, Separović, Zvonimir, Kazneno pravo (posebni dio), Masmedia, Zagreb, 1999., str. 249. Isto: Turković, Ksenija, Maršavelski, Aleksandar: "Nacrt posebnog dijela novog Kaznenog zakona - pregled pet glava", Hrvatski ljetopis za kazneno pravo i praksu (Zagreb), vol. 17, broj 2/2010, str. 503-551. Redakcija čl. 209. KZ/97, predstavljala je, s druge strane, "neznatno poboljšanu formulaciju dotadašnjeg čl. 92. KZRH-a upravo dodavanjem "izbjegavanjem zaposlenja", "mijenjanjem mjesta boravka ili prebivališta", "otuđivanjem imovine", jer je na to ukazivala potreba sudske prakse. Smatralo se da se time "pojačava zaštita uzdržavanih osoba putem kaznenopravne represije i modaliteta ponašanja koji do sada nisu bili opisani u zakonu." Konačni prijedlog Kaznenog zakona, Zagreb, lipanj 1997., str. 198.

29 Bačić-Šeparović, op. cit. (bilj. 13), str. 153. "Poboljšanjem" ranijeg zakonskog opisa djela izričito je proširena kaznena zona, jer je razlika između neprihvaćanja i izbjegavanja zaposlenja jasna, a novi su se načini (npr. otuđivanje imovine) mogli tumačiti, no ne i u dosadašnjoj sudskoj praksi, kao "na drugi način". Sada su neki od tih načina postali dio zakonskog obilježja ovoga kaznenog djela što omogućava nedvojbeno postojanje djela i kod takvih ponašanja." Horvatić, Željko, Novo hrvatsko kazneno pravo, Organizator, Zagreb, 1997., str. 438.

30 Bačić-Pavlović, op. cit. (bilj. 4), str. 739.

31 ŽsSt broj: Kžzd-73/2018-5 od 4. rujna 2018.

32 ŽsBj broj: Kžzd-30/2019-2 od 4. srpnja 2019.

33 Žsši broj: Kžzd-23/18-4 od 15. studenoga 2018., ŽsZg broj: Kžzd-102/18-4 od 3. siječnja 2019. 
postojanje obveze..$^{34}$ Izostanak "većeg osobnog angažmana" na osiguranju novčanih sredstava za uzdržavanje djece predstavlja ponašanje kojim se ostvaruju sva bitna obilježja kaznenog djela povrede dužnosti uzdržavanja iz čl. 172. st. 2. i 1. KZ-a. ${ }^{35}$ "Kako okrivljenik živi i radi u Njemačkoj, očito je da ostvaruje dovoljno sredstava kojima bi mogao plaćati uzdržavanje maloljetnih oštećenika i podmiriti zaostale obroke uzdržavanja." ${ }^{36}$ Siromaštvo i zdravstveno stanje nisu osnovani razlozi za neplaćanje uzdržavanja, jer je počiniteljica imala mogućnost tražiti izmjenu presude o uzdržavanju, što nije učinila. ${ }^{37}$ "Već sama činjenica da je okrivljenik radno sposoban te da je u kritičnom razdoblju ostvarivao određenu zaradu, kao i to da u tom istom razdoblju ni na koji način nije pokazao odgovornost da iz tako ostvarenih prihoda redovno doprinosi za uzdržavanje svog djeteta, niti je pokrenuo bilo kakav postupak za smanjenje iznosa visine uzdržavanja, o kojem se nedvojbeno ne može odlučivati u ovom kaznenom postupku, već isključivo u parničnom kao i činjenica da je u svojoj obrani iskazao kako je mislio da nije dužan plaćati alimentaciju zbog toga što nije viđao sina, ukazuje na namjeru okrivljenika da ne plaća ništa, ignorirajući očigledno postojanje pravomoćne sudske odluke na temelju koje je to bio dužan činiti."38 "Sud prvog stupnja je optuženiku osnovano naložio posebnu obvezu iz čl. 62. st. 1. t. 1. KZ/11 tj. da popravi štetu na način da u roku od jedne godine od pravomoćnosti presude plati naznačeni iznos, koju štetu je prouzročio počinjenjem kaznenih djela povrede dužnosti uzdržavanja iz čl. 172. st. 2. u svezi st. 1. KZ/11, s obzirom da je sposoban za privređivanje, što znači da se može zaposliti i ostvarivati prihode, a što i sam potvrđuje u žalbi navodeći da uskoro očekuje zaposlenje." ${ }^{39}$ "Novčane potpore prema posebnom zakonu o pravima iz roditeljstva ${ }^{40}$ u pravilu ne mogu biti predmetom ovrhe ili osiguranja. Međutim, zaposlenom i samozaposlenom roditelju pripada pravo na naknadu plaće, a roditeljima izvan sustava rada novčana potpora tijekom brige o novorođenom djetetu. Time država osigurava financijsku pomoć kao izvjesni supstitut plaće, u razdoblju oko poroda i neposredno nakon rođenja djeteta. To ne znači da roditelj ima zabranu novčana sredstva uporabiti i u zbrinjavanju svog drugog maloljetnog djeteta."41 "Koliko god bile teške materijalne prilike optužene, toliko je još više potreban njezin angažman oko pronalaženja bilo posla, bilo izvora prihoda iz čega će plaćati dužno uzdržavanje. Uostalom, ako su materijalne prilike optužene teške i složene, sasvim je sigurno da niti prilike oca maloljetnog oštećenika nisu mnogo drugačije, pa je potpuno neprihvatljivo i u pravnom i u životnom smislu da se jednostranom odlukom optužene svi troškovi uzdržavanja jednostavno prevaljuju na drugog roditelja." 42

34 Žš̌i broj: Kžzd-18/2018-4 od 12. rujna 2019.

ŽsSt broj: Kžzd-80/16 od 1. prosinca 2016.

ŽsSi broj 5 Kžzd-7/17-5 od 18. kolovoza 2017.

ŽsVu broj: Kžzd-4/2020-6 od 11. svibnja 2020.

ŽsSB broj: 21 Kžzd-10/2017-4 od 29. siječnja 2018.

ŽsVž broj: 5 Kžzd-12/17-4 od 11. travnja 2017.

Zakon o rodiljnim i roditeljskim potporama (NN 85/08, 34/11, 54/13, 152/14, 59/17, 37/20).

ŽsRi broj: Kžzd-24/2016-4 od 30. studenoga 2016.

42 ŽsZg broj: 15 Kžzd-43/2019-4 od 13. ožujka 2019. 


\section{OPRAVDANI RAZLOZI ZA ISKLJUČENJE PROTUPRAVNOSTI}

Privremena nesposobnost za rad načelno isključuje protupravnost radnje okrivljenika. ${ }^{43}$ Počinitelj mora dokazati opravdanost svojih razloga, s time da se opravdanost razloga u pravilu ocjenjuje prema objektivnim mjerilima. ${ }^{44}$ "Inkriminirano razdoblje obuhvaća zimske mjesece, kada je smanjena mogućnost rada u nadnicama i poljoprivredi, čime se optuženik bavi, što opravdava neredovitost plaćanja dužnih rata uzdržavanja, ali i ukazuje da kod optuženika nema namjere neplaćanja uzdržavanja za svoju maloljetnu djecu, jer je, kada je to bio u mogućnosti, doprinosio za njihovo uzdržavanje." 45 "Bez obzira što prima malu mirovinu i skrbi o članovima obitelji, imajući u vidu da se bavi i poljoprivredom, te da nema dokaza o tome da bi bio nesposoban za rad, neosnovana je žalba optuženika da je imao opravdane razloge za neispunjenje obveze uzdržavanja." ${ }^{46}$ Ukoliko je osuđenik u nemogućnosti doprinositi za plaćanje alimentacije, na što je obvezan pravomoćnom presudom, može tražiti u parničnom postupku ukidanje takve obveze, pogotovo imajući u vidu njegovu invalidnost i primanje (male) invalidnine na koju se poziva. ${ }^{47}$ Blokada računa optuženika, zbog dugovanja prema Republici Hrvatskoj s osnove isplate privremenog uzdržavanja za njegovu maloljetnu kćerku, dakle, upravo iz razloga što nije ispunjavao svoju zakonsku obvezu uzdržavanja, ne predstavlja opravdani razlog u smislu čl. 172. st. 3. KZ-a zbog kojega optuženik nije u mogućnosti plaćati uzdržavanje. ${ }^{48}$ "Trenutna nemogućnost" plaćanja uzdržavanja nije opravdan razlog za neizvršavanje obveze, a navod da tek od iduće godine planira poljoprivredno zemljište koje posjeduje dati u zakup radi ostvarivanja barem dijela sredstava, samo dodatno ukazuje na njegov negativistički stav prema naloženoj obvezi ${ }^{49}$ Iznenadna bolest na koju se sada poziva počinitelj, nije opravdani razlog zbog kojega nije mogao izvršiti naloženu obvezu, budući da je na bolničkom liječenju bio manje od sva mjeseca, a otpušten je na kućnu njegu dobrog općeg stanja, uz preporuku izbjegavanja težih fizičkih napora. ${ }^{50}$ "Svakako je obveza roditelja angažirati se da svakom svojem djetetu pruži odgovarajuću roditeljsku skrb, koja obuhvaća i materijalni dio skrbi radi osiguranja životne egzistencije, u čemu roditelj mora uložiti i neke povećane napore. Okrivljenica ima završeno osnovnoškolsko obrazovanje, što znači da nema nikakvu konkretnu kvalifikaciju, podaci Hrvatskog zavoda za zapošljavanje potvrđuju da je nezaposlena i u njihovoj evidenciji i nesporno vodi brigu o troje djece mlađe životne dobi iz izvanbračne zajednice, stoga na njenoj strani postoje objektivni razlozi što ne ispunjava obvezu,

43 ŽsSt broj: Kžzd-4/2019-5 od 5. veljače 2019.

44 ŽsRi broj: Kžzd-24/2016-4 od 30. studenoga 2016.

45 ŽsBj broj: Kžm-2/2015-3 od 5. veljače 2015.

46 ŽsBj broj: Kžzd-36/2019-4 od 12. rujna 2019.

47 ŽsKa broj: Kžmp-21/2019-3 od 16. prosinca 2019.

48 ŽsŠi broj: Kžzd-18/2018-4 od 12. rujna 2019.

49 ŽsOs broj: Kžzd-86/2019-4 od 24. listopada 2019.

50 ŽsBj broj: Kžzd-1/2019-4 od 7. veljače 2019. 
dok ne postoje dokazi koji bi potvrdili da se radilo o izbjegavanju zapošljavanja, stoga se radi o uvjetima iz čl. 172. st. 3. KZ." ${ }^{11}$ U potonjem primjeru neopravdano se honorira neškolovanost, bez propitkivanja razloga zašto počiniteljica ima samo završenu osnovnu školu. Odluka zapravo odudara od svih ostalih presuda u kojima se zaposlene i obrazovane osobe "potiču" na dodatni rad i angažman, čak ih sudovi upućuju na rad za nadnice, dok se u ovom primjeru lakonski zaključuje da je to komparativna prednost okrivljenice i razlog za neplaćanje uzdržavanja. Dodatno valja ukazati i na činjenicu da se uredno ističe kako roditelj mora voditi (jednaku) brigu o svakom svom djetetu, a ovdje je očigledno da je počiniteljica napustila jedno svoje dijete, međutim, dobra je majka jer se brine za troje druge djece koje je rodila drugom čovjeku, s kojim živi u izvanbračnoj zajednici. Poruka koja se šalje ovakvim opravdavanjem neplaćanja uzdržavanja apsolutno je negativistička. Ako prijavljena osoba iz opravdanih razloga ne može izvršavati dužnost i ispunjavati obvezu uzdržavanja (ultra posse nemo tenetur - nitko nije obvezan činiti nemoguće), na strani obveznika uzdržavanja ne postoji subjektivno obilježje kaznenog djela. ${ }^{52}$ "To što je okrivljeni, po vlastitim riječima, povremeno nekad davao uzdržavanje za maloljetnog oštećenika, kao i to što nije (bio) zaposlen, svakako nisu opravdani razlozi za propuštanje davanja uzdržavanja." ${ }^{33}$ "Potrebno je analizirati tri tvrdnje optuženika koje mogu predstavljati značajne indicije u korist zaključka kako optuženik nije izvršio neplaćanje s namjerom. Značajno je utvrditi odgovara li istini navod da je sastavio oporuku u korist oštećenice i ocijeniti vjerodostojnost navoda kako nije pokrenuo postupak ukidanja obveze uzdržavanja iz razloga što se bojao da će umrijeti (uslijed bolesti gušterače), jer bi u sadašnjoj situaciji (kada u trenutku smrti postoji obveza uzdržavanja pokojnika prema uzdržavanoj osobi) oštećenica naslijedila njegovu njemačku mirovinu. Nadalje, potrebno je ocijeniti vjerodostojnost tvrdnje optuženika kako je voljan odreći se svog dijela suvlasništva na zemlji koja je u suvlasništvu optuženika i oštećenice u njenu korist, kako bi se zemlja prodala i ona naplatila iz kupovnine. Ako se utvrdi sve navedeno, nikako ne možemo zaključivati da optuženik ima negativan stav u vezi financijskih izdvajanja u korist oštećenice." 54 Suprotno, darovanje "posebne imovine" i pola bračne stečevine u nekretninama, tako da vrijednost darovanih nekretnina djeci prelazi 100.000 eura te ostavljanje supruzi i djeci, prilikom odlaska iz kuće, cjelokupne ušteđevine od 30.000,00 kuna, ne opravdava neplaćanje uzdržavanja. ${ }^{55}$ Prilikom vrednovanja okolnosti značajnih za odluku o opstojnosti kaznenog djela, uvijek valja voditi računa o mogućnosti ukidanja ili preinačenja obveze uzdržavanja

51 ŽsRi broj: Kžzd-29/2018-4 od 16. rujna 2018.

52 Bačić-Pavlović, op. cit. (bilj. 4), str. 740.

ŽsZg broj: Kžzd-55/17-4 od 22. ožujka 2017.

54 ŽsBj broj: Kž-1/2017-4 od 6. srpnja 2017.

55 ŽsSt broj: Kžzd-4/2019-5 od 5. veljače 2019. 
kroz parnični postupak, ${ }^{56}$ odnosno nagodbom, ${ }^{57}$ zbog promjene okolnosti u vezi s obvezom uzdržavanja (čl. 285. OZ-a).

\section{BAGATELNO DJELO}

Za opstojnost kaznenog djela povrede dužnosti uzdržavanja ne smije se raditi o bagatelnom slučaju, već ozbiljnijoj povredi zakonskih dužnosti. ${ }^{58}$ Stoga se u praksi žrtvama savjetuje podnošenje kaznene prijave nakon proteka određenog vremena od trenutka početka radnje neizvršavanja obveze. Usprkos činjenici da nikome nije jednostavno živjeti bez osnovnih sredstava za život ${ }^{59}$ te uz puno uvažavanje činjenice da se kazneni progon za proučavano kazneno djelo vodi ex officio, što ukazuje na prepoznat problem po zakonodavcu, nije svrhovito vođenje kaznenog postupka u slučajevima kada je kršenje obveze minimalno. Objektivan rok za iniciranje kaznenog postupka otprilike je šest mjeseci od trenutka kada je potencijalni počinitelj započeo kršiti zakonsku obvezu uzdržavanja. U pravilu je riječ o plaćanju uzdržavanja, davanju u novcu, slijedom čega po isteku navedenog razdoblja dolazi do nakupljanja određene svote novca, koja ukupno predstavlja nezanemariv iznos što ga treba naplatiti od počinitelja kaznenog djela. S druge strane, nužno je pokazati razumijevanje za žrtve i njihove potrebe (svakodnevne, mjesečne, kontinuirane). ${ }^{60}$ Nisu rijetke životne situacije da uzdržavana osoba nema drugih primanja osim toga, gdje nije pravedno tražiti strpljenje dok državni aparat oblikovan u kaznenu represiju ne zaključi da se nakupilo "dovoljno" duga da više ne možemo govoriti o beznačajnom djelu. Sudska praksa obvezna je iznjedriti određenu granicu, premda je teško definirati jednu jedinstvenu do koje se, uvjetno rečeno, tolerira neizvršavanje obveze davanja uzdržavanja, kako bi osigurala jednakost svih pred zakonom. Ne treba dozvoliti neselektivno i osvetničko ili obijesno prijavljivanje obveznika davanja uzdržavanja, ali prava žrtava beziznimno treba staviti ispred uskogrudnih razloga kršitelja obveze, naročito u slučaju neplaćanja alimentacije za djecu. Počinitelj mora pokazati dugotrajan i krajnje negativan stav prema svojoj obvezi uzdržavanja. ${ }^{61}$

56 ŽsKa broj: Kžmp-21/2019-3 od 16. prosinca 2019.; ŽsSt broj: Kžzd-9/2020-5 od 5. veljače 2020.; ŽsSB broj: 21 Kžzd-10/2017-4 od 29. siječnja 2018.

57 Žs ̌̌i broj: Kžzd-23/18-4 od 15. studenoga 2018.

58 Bačić-Šeparović, op. cit. (bilj. 13), str. 153.

59 "Upravo sudska odluka o obvezi redovitog mjesečnog uzdržavanja djece jamči djeci da će iz dobivenih sredstava biti u mogućnosti podmirivati svoje kontinuirane mjesečne potrebe, te ista u stvari predstavlja garanciju da dijete neće biti prepušteno samovolji obvezanog roditelja da plaća dužno uzdržavanje prema vlastitom nahođenju ili na uporno inzistiranje djeteta u vrijeme i u visini kada i kako obvezani roditelj to odluči" (ŽsOs broj: Kžzd-38/2019-4 od 6. lipnja 2019.).

60 ŽsRi broj: Kžzd-24/2016-4 od 30. studenoga 2016.

${ }_{61}$ ŽsBj broj: Kžm-31/2014 od 30. prosinca 2014., ŽsBj broj: Kžm-2/2015-3 od 5. veljače 2015.; ŽsBj broj: Kžzd-31/2019-4 od 14. studenoga 2019. 


\section{POJMOVNO ODREĐENJE TRAJNIH KAZNENIH DJELA}

Trajna kaznena djela (njem. Dauerdelikt) jesu djela u kojima radnja nije dovršena, već se održava neprekidnom namjernom voljom ${ }^{62}$ počinitelja sve dok traje protupravno stanje koje je stvorio. Trajna kaznena djela uglavnom su jednostavna kaznena djela. ${ }^{63}$ "Tzv. trajna kaznena djela karakterizira protupravno stanje koje je svojom radnjom stvorio počinitelj i održava ga svojom voljom. Kazneno djelo postoji, obnavlja se sve do trenutka kad počinitelj odluči to stanje prekinuti, bilo svojom vlastitom voljom ili pak je na to prisiljen djelovanjem vanjskih okolnosti." 64 Kod trajnog kaznenog djela radi se o djelu čijem zakonskom biću (njegovu nepravu) pripada i trajanje odnosno održavanje protupravnog stanja stvorenog radnjom izvršenja tog djela, a sve to javlja se kao jedna cjelina, što izravno ili smisleno proizlazi iz bića djela. ${ }^{65} \mathrm{U}$ pravilu je riječ o formalnim kaznenim djelima. Njima u širem smislu pripadaju i kaznena djela nečinjenjem kod kojih počinitelj kontinuirano krši neku obvezu na činjenje ${ }^{66}$ održavajući tako protupravno stanje, primjerice kazneno djelo povrede dužnosti uzdržavanja. ${ }^{67}$ Potrebno je pažljivo razlikovati trajna kaznena djela od kaznenih djela stanja (njem. Zustandsdelikten) u slučaju kada se podudaraju formalno dovršenje djela (njem. Vollendung) i materijalno dovršenje djela (njem. Beendigung), primjerice u slučaju razbojništva. ${ }^{68}$

\section{NAČINI PREKIDA KONTINUITETA RADNJE KAZNENOG DJELA}

Vremenska dimenzija dovršetka radnje trajnih kaznenih djela nije sistematično obrađena u teoriji kaznenog prava. Uglavnom se razmatra kod zastare. Radnja kaznenog djela može trajati kratko, ali i dulje vremensko razdoblje, posebno kod trajnih kaznenih djela. ${ }^{69}$ Čim dulje traje, otvara se i više različitih mogućnosti ili načina za prekid protupravnog stanja. Predmetno uzdržavanje samo po sebi, po prirodi stvari, podrazumijeva jedan dulji period. Jedinstvenu radnju kaznenog djela

62 BGH, 9. srpnja 2015. - 3 StR 537/14. Creifelds, Carl, Rechtswörterbuch, 23. Auflage, C. H. Beck, München, 2019., str. 319. Fischer, Thomas, Strafgesetzbuch mit Nebengesetzen, 65. Auflage, Verlag C. H. Beck oHG, München, 2018., str. 479. Roxin, Claus, Strafrecht Allgemeiner Teil, Band I, Grundlagen, Der Aufbau der Verbrechenslehre, 4. Auflage, Verlag C. H. Bech, München, 2006., str. 330.

63 Roxin, ibid, str. 331.

64 Horvatić, Željko, Novoselec, Petar, Kazneno pravo (opći dio), Ministarstvo unutarnjih poslova Republike Hrvatske, Policijska akademija, Zagreb, 1999., str. 173. Horvatić, Željko, Derenčinović, Davor, Cvitanović, Leo, Kazneno pravo, Opći dio 2: kazneno djelo i kaznenopravne sankcije, Pravni fakultet Sveučilišta u Zagrebu, Zagreb, 2017., str. 33.

65 Bačić, Franjo, Krivično pravo, Opći dio, Četvrto, izmijenjeno izdanje, Informator, Zagreb, 1995., str. 109.

${ }_{66}$ Mora postojati čin koji pridonosi počinjenju djelu ili koji barem služi za održavanje protupravnog stanja (BGH, 14. ožujka 2012. - 2 StR 561/11).

67 Horvatić, Derenčinović, Cvitanović, op. cit. (bilj. 36), str. 34.

68 Creifelds, op. cit. (bilj. 34), str. 320.

69 Fischer, (op. cit. bilj. 34), str. 49. 
kod povrede dužnosti uzdržavanja čine radnja kojom se stvara protupravno stanje i one koje služe njegovu održavanju, primjerice, neplaćanje alimentacije za dijete svaki mjesec. ${ }^{70}$ Strogo uzevši zakonske norme, riječ je o istom kaznenom djelu, na štetu iste žrtve, $\mathrm{s}$ istim modusom počinjenja. S druge strane, tumačenje prava u obliku sudske presude, nema snagu zakona i obvezuje samo stranke u konkretnom postupku i samo za slučaj (predmet, spor) za koje je dano.

\subsection{Svojevoljni prekid protupravnog stanja}

Protupravnost jednom započete radnje propuštanja obveze redovitog plaćanja uzdržavanja završava u trenutku kad počinitelj započne ispunjavati svoju obvezu. Kod kaznenog djela povrede dužnosti uzdržavanja to znači neprekinuti slijed izvršenja jednog (produljenog) djela sve do momenta kad se počinitelj svojevoljno odluči izvršavati zakonsku obvezu uzdržavanja. U pogledu kvalifikacije djela, to bi značilo da sve dok on svojevoljno ${ }^{71}$ ne počne izvršavati obvezu davanja uzdržavanja, postoji samo jedno kazneno djelo. Upitno je stoga kazneno procesuiranje svakog počinitelja koji ustraje na nečinjenju, neplaćanju uzdržavanja, ukoliko spozna da jednom započeto plaćanje znači izlaganje opasnosti da iznova dođe na udar kaznene represije, ako se naknadno, bez obzira na razloge i/ili motive, ponovno odluči ne ispunjavati obvezu uzdržavanja. Trajno održavanje protupravnog stanja i kontinuirano neizvršavanje zakonom nametnute obveze, posljedično znači da prethodna osuda za isto kazneno djelo i na štetu iste žrtve predstavlja zakonsku zapreku za ponovno suđenje o istoj stvari, zbog kršenja načela ne bis in idem. Prekid protupravnog stanja što ga je vlastitim radnjama prouzročio počinitelj vraća mu se poput bumeranga, jer činjenično omogućava tijelima kaznenog progona otvaranje novog predmeta i sljedeće suđenje zbog kršenja identične obveze.

\subsection{Održavanje protupravnog stanja osudom}

"Presuda za kazneno djelo povrede dužnosti uzdržavanja iz čl. 172. st. 2. i 1. KZ odnosi se na trajno kazneno djelo i takva presuda je i jedina moguća, jer se radi o jednom kaznenom djelu koje je sankcionirano takvom osudom koja u sebi uključuje i daljnje održavanje stanja - neplaćanje uzdržavanja. Ukoliko je počinitelj osuđen zbog neplaćanja u odnosu na iste osobe, za razdoblja koja se konsekutivno nastavljaju jedno na drugo, čineći vremensku cjelinu odnosno vremenski kontinuitet kaznenog djela, okrivljenik ne može biti ponovno procesuiran, jer bi time bilo povrijeđeno načelo ne bis in idem, s obzirom da bi se u novom postupku, po novoj

70 Novoselec, Martinović, op. cit. (bilj. 6), str. 340-341.

${ }^{71}$ Usp. ŽsSt broj: Kžzd-55/2018-2 od 26. lipnja 2018. Okrivljenik u navedenom predmetu nije plaćao uzdržavanje pune tri godine, nakon čega je jednostavno svojevoljno počeo doprinositi i to s većim iznosom od presuđenog, na temelju dogovora s bivšom suprugom. 
optužnici, radilo o presuđenoj stvari."72 Isto stajalište izraženo je i u jednoj sudskoj odluci starijeg datuma, ${ }^{73}$ u kontekstu razmatranja načela zabrane reformatio in peius, tvrdnjom da ono "nije povrijeđeno time što je pobijanom presudom, sukladno izmijenjenom optužnom aktu, proširen period u kojem optuženik nije plaćao dužno uzdržavanje za oštećene, te time i ukupni iznos neplaćenog uzdržavanja, budući da je kazneno djelo povrede dužnosti uzdržavanja trajno kazneno djelo, traje tako dugo dok se povređuje dužnost uzdržavanja jednim od modaliteta radnje počinjenja kaznenog djela i sve radnje koje su poduzete tijekom trajanja tog protupravnog stanja predstavljaju jedno kazneno djelo. S obzirom da je predmetno kazneno djelo povrede dužnosti uzdržavanja trajalo i nakon datuma podizanja optužnog akta, do kojeg datuma je u prvoj prvostupanjskoj presudi optuženik presuđen da je odbijao plaćati uzdržavanje za oštećene, državni odvjetnik je bio ovlašten proširiti optužbu za povredu dužnosti uzdržavanja i na period nakon 30. siječnja 2006. godine, budući da protupravno stanje nije prestalo do navedenog datuma, što više, s obzirom da se radi o jednom kaznenom djelu, državni odvjetnik nije niti imao mogućnost za period nakon 30. siječnja 2006. godine podnijeti novi optužni akt." Ogluha na (pravomoćnu) sudsku presudu o optužbi za kazneno djelo predstavlja zasebno kazneno djelo neizvršavanje sudske odluke (čl. 311. st. 1. KZ-a), ali samo u slučaju da je počinitelj službena ili odgovorna osoba. Kvalificirani oblik djela iz čl. 311. st. 2. KZ-a, odnosno čl. 311. st. 3. KZ-a, doduše, može počiniti bilo tko, ali ako se radi o kršenju sigurnosnih mjera ili nepridržavanju (samostalne) mjere opreza. Posebne obveze koje se nalažu počinitelju kaznenog djela povrede dužnosti uzdržavanja kaznenopravne su sankcije koje ne ulaze u krug sigurnosnih mjera ili mjera opreza.

\subsubsection{Kršenje posebnih obveza}

Blage kaznene sankcije koje izriču hrvatski sudovi, gdje dominira uvjetna osuda, ukazuju na neučinkovitu zaštitu povrijeđenog objekta radnje i izostanak specijalne prevencije. Kršenje posebne obveze ${ }^{74}$ u vidu sudskog naloga da osuđena osoba ubuduće uredno izvršava obvezu uzdržavanja, tek iznimno dovodi do opoziva uvjetne osude. ${ }^{75}$ Pritom žrtva mora dati svoj prijedlog ili pokrenuti inicijativu, dok državni odvjetnik mora dobro paziti da ne prođu rokovi za opoziv uvjetne

72 ŽsVu broj: Kžzd-16/2019-6 od 9. prosinca 2019. Naknadno je isti sud, u ponovljenom postupku, reterirao od prvobitnog tumačenja, ustvrdivši da je "okr. uplatama nakon provedenog ispitivanja kod policijskog istražitelja uzrokovala prekid protupravnog stanja, zbog čega se u ovom kaznenom postupku ne može raditi o presuđenoj stvari" (ŽsVu broj: Kžzd-4/2020-6 od 11. svibnja 2020.).

73 ŽsVž broj: Kž-210/08-4 od 8. prosinca 2008.

74 "Kada je sud prvoga stupnja naložio posebnu obvezu da optuženik "popravi štetu", tada je zapravo apostrofirao sveukupnu obvezu optuženika plaćanjem novčanog iznosa majci i zakonskoj zastupnici u ostavljenom roku" (ŽsVu 2 Kžzd-1/2020-7 od 29. siječnja 2020.). Isto: ŽsVž broj: 5 Kžzd-12/17-4 od 11. travnja 2017. "Iznos koji žrtvama isplati nadležni centar za socijalnu skrb na ime privremenog uzdržavanja, od optuženika treba oduzeti kao imovinsku korist ostvarenu kaznenim djelom" (ŽsSt broj: Kžzd-45/16 od 7. srpnja 2016.). Privremeno uzdržavanje regulirano je Zakonom o privremenom uzdržavanju (NN 92/14).

75 ŽsKa broj: Kž-110/2017-3 od 17. travnja 2018.; ŽsBj broj: Kžzd-1/2019-4 od 7. veljače 2019.; ŽsDu broj: Kžzd-16/17-3 od 12. listopada 2017.; ŽsZg broj: Kžzd-28/2019-4 od 4. ožujka 2019.; OsVt broj: Kvm-16/2017-7, Kzd-2/2016 od 2. lipnja 2017.; OsVt broj: Kvm-1/2017-5, Kzd-36/15 od 27. siječnja 2017.; OsVt broj: 6 Kvm-6/17-7 (Kzd-28/15) od 27. veljače 2017. 
osude. Često se produljuju, odnosno određuju novi rokovi ${ }^{76}$ za ispunjenje posebne obveze uzdržavanja. Po plaćanju, u pravilu se obustavlja postupak za opoziv uvjetne osude ako osuđenik pokaže imalo dobre volje da shvaća ozbiljnost obveze prema uzdržavanoj osobi i da će ubuduće uredno izvršavati naloženu (posebnu) obvezu. ${ }^{77}$ Inicijativu za opoziv uvjetne osude najčešće daju žrtve, odnosno njihovi zakonski zastupnici, premda se radi o kaznenom djelu koje se progoni po službenoj dužnosti, tako da nema zapreke da državno odvjetništvo, nakon kratkog prikupljanja podataka o ispunjenju obveze uzdržavanja, samoinicijativno ne pokrene postupak opoziva uvjetne osude.

\subsection{Prekidanje protupravnog stanja kaznenim procesom}

Provedba kaznenog postupka, sama za sebe, bez osude počinitelja, ne prekida protupravno stanje uspostavljeno počiniteljevim propuštanjem izvršavanja dužnosti uzdržavanja druge osobe. "Kazneno djelo povrede uzdržavanja je trajno kazneno djelo koje se smatra dovršenim u trenutku kada prestane protupravno stanje održavano izvršavanjem takvih radnji kojim se izbjegava davanje uzdržavanja. Radi se o posebnom obliku trajnog kaznenog djela svojstvenog kaznenim djelima nečinjenjem, kod kojih izvršenje traje sve dok počinitelj ne ispuni obvezu i na taj način prekine protupravno stanje ili sve dok protiv njega ne bude pokrenut kazneni postupak. Kada je raniji kazneni postupak pokrenut, time je prekinuto protupravno stanje, zbog čega nema govora o presuđenoj stvari, ako je optuženik i nakon toga nastavio s neispunjavanjem obveze koju ima na temelju ovršne isprave." ${ }^{178} \mathrm{Njemačka}$ sudska praksa po pitanju trajnih kaznenih djela tumači da se prekida protupravno stanje u slučaju pravomoćne sudske presude. ${ }^{79}$ Riječ je o djelovanju vanjskih uzroka, izvan moći počinitelja, pri čemu posljedice takvog uredovanja od strane države nastupaju po sili zakona. Procesni identitet djela (njem. der prozessualen Tatidentität) zahtijeva razmatranje da li radnje koje ulaze u biće kaznenog djela tvore jedinstvenu životnu cjelinu. ${ }^{80}$ Usporedbe radi, kod utaje poreza, novostvorena odluka (njem. Tatentschluß) o izbjegavanju obveze plaćanja poreza, nakon prethodne osude za određeno razdoblje, može biti prekretnica za tumačenje da je sljedeće (trajno) kazneno djelo procesno neovisno kazneno djelo. ${ }^{81}$ Stoga u slučaju neplaćanja obveze uzdržavanja, naknadna odluka odnosno nastavak ranije prakse neplaćanja alimentacije usprkos zakonskoj obvezi i ranijoj osudi, može po sudu biti shvaćeno kao novo kazneno djelo. Tada ne stoji prigovor presuđene stvari kao

76 OsVt broj: Kv2 Kvm-10/2018-5 od 25. svibnja 2018.

77 OsVt broj: Kvm-8/2019-5 od 28. svibnja 2019., OsVt broj: Kzd-24/2018-5 od 11. prosinca 2018., OsVt broj: Kvm-1/2017-5, Kzd-36/15 od 27. siječnja 2017., OsVt broj: Kvm-17/2017-6 od 29. rujna 2017.

78 ŽsVG broj: 10 Kž-298/2017-3 od 17. siječnja 2019.

79 BGH, 23. 10. 2008. - 1 StR 526/08.

80 BGH, 7. 2. 2012. - 1 StR 542/11.

81 BGH, 24. 11. 2004. - 5 StR 206/04. 
Dr. sc. Bruno Moslavac: Prekid kontinuiteta radnje trajnog kaznenog djela povrede dužnosti uzdržavanja Zbornik radova Pravnog fakulteta u Splitu, god. 58, 3/2021, str. 763-783

procesno-pravni prigovor i nema zapreke za novo suđenje, premda samo kazneno djelo, po materijalnom pravu, nesporno predstavlja trajno kazneno djelo.

\subsection{Drugi način prekida protupravnog stanja}

"Činjenica naknadnog podmirenja dugovanog iznosa uzdržavanja iz utuženog vremenskog perioda, i to prisilnim obustavama na plaći optuženika, nije od utjecaja na opstojnost terećenih kaznenih djela." ${ }^{82}$ "Prisilno naplaćeni iznos sud je oduzeo od ukupno neplaćenog iznosa uzdržavanja, tako da se u konkretnom slučaju ne može raditi o pravomoćno presuđenoj stvari." 83 Činjenica da se majka djeteta ili zakonska zastupnica oštećenice nije naplaćivala putem ovršnog zakona, ne utječe na opstojnost kaznenog djela ${ }^{84} \mathrm{Ne}$ postoji zakonski zahtjev da se, prije iniciranja kaznenog postupka, oštećenik ili zakonski zastupnik u slučaju djece žrtava kaznenog djela nedavanja uzdržavanja, mora sa zahtjevom za namirenje obratiti građanskom, parničnom sudu ili drugom tijelu koje provodi ovršni postupak. "Davanje na ruke iznosa uzdržavanja zakonskoj zastupnici djece, osiguravanje svake godine ogrjeva u količini od cca $10 \mathrm{~m} 3$ drva, voženje djece na kontrolu u Zagreb i plaćanje troškova odlaska u Zagreb, ne utječu na presudu, jer se u konkretnom slučaju optuženik nije dogovorio sa zakonskom zastupnicom ${ }^{85}$ da se navedena davanja trebaju odbijati od presuđenog uzdržavanja."86

\section{POREDBENA ZAKONODAVSTVA}

Švicarski kazneni zakon ${ }^{87}$ normira kazneno djelo zanemarivanje obveza uzdržavanja (njem. Vernachlässigung von Unterhaltspflichten) u čl. 217. st. 1. gdje propisuje da onaj tko ne ispuni obveze uzdržavanja ili uzdržavanja prema obiteljskom zakonu, iako ima ili bi mogao imati sredstva za to, bit će kažnjen na zahtjev zatvorom do tri godine ili novčanom kaznom. Specifičan zahtjev po pitanju podnošenja zahtjeva (prijedloga) za kazneni progon utvrđen je u čl. 217. st. 2. SStGB-a, prema kojem javna vlast i agencije koje kantoni imenuju također imaju pravo podnošenja zahtjeva. Naznačena je i svrha podnošenja prijedloga za kazneni progon, označena kao interes obitelji. Riječ je također o kaznenom djelu nečinjenja (njem. (Un-)Tätigkeitsdelikt). Inkriminacija u prvi plan stavlja ekonomski i na drugi način slabiju, ovisnu osobu.

82 Žs ̌̌i broj: Kžzd-23/18-4 od 15. studenoga 2018.

83 ŽsBj broj: Kžzd-31/2019-4 od 14. studenoga 2019.

84 ŽsZg broj: Kžzd-102/18-4 od 3. siječnja 2019.

85 V. ŽsVž broj: 5 Kžzd-65/16-5 od 12. prosinca 2017., ŽsSt broj: Kžzd-55/2018-2 od 26. lipnja 2018.

86 ŽsVu broj: 1 Kžzd-11/2018-6 od 28. lipnja 2016.

87 Schweizerisches Strafgesetzbuch vom 21. Dezember 1937 (Stand am 1. Juli 2020; dalje u tekstu: SStGB). 
Kazenski zakonik Republike Slovenije ${ }^{88}$ propisuje kazneno djelo "neplačevanje preživnine", gdje u čl. 194. st. 1. normira da će kaznom zatvora do jedne godine biti kažnjen počinitelj koji, premda bi to mogao, ne daje uzdržavanje za osobu koju je po zakonu dužan uzdržavati i čija je visina utvrđena ovršnom odlukom. Ukoliko je zbog nedavanja uzdržavanja ugroženo ili bi moglo biti ugroženo uzdržavanje žrtve, ili ako počinitelj izbjegava davanje uzdržavanja, može mu biti izrečena kazna zatvora do tri godine (čl. 194. st. 2. KZS-a). Po pitanju izbjegavanja davanja uzdržavanja vidljiva je zajednička pravna prošlost hrvatskog i slovenskog zakonodavstva. Ako sud izrekne uvjetnu kaznu, može naložiti počinitelju kaznenog djela iz čl. 194. st. 1. KZS-a ili čl. 194. st. 2. KZS-a da redovito plaća uzdržavanje, ali može ga obvezati da plati i dospjelo novčano uzdržavanje ili druge dodijeljene obveze koje proizlaze iz uzdržavanja (čl. 194. st. 3. KZS-a).

Krivični zakonik Crne Gore ${ }^{89}$ pod nazivom "nedavanje izdržavanja" u čl. 221. st. 1. propisuje da djelo čini onaj (svatko) koji "ne daje izdržavanje za lice koje je po zakonu dužan da izdržava, a ta dužnost je utvrđena izvršnom sudskom odlukom ili izvršnim poravnanjem pred sudom ili drugim nadležnim organom, u iznosu i na način kako je to odlukom odnosno poravnanjem utvrđeno. Zapriječena kazna za temeljni oblik kaznenog djela jest novčana kazna ili zatvor do dvije godine. Kvalificirani oblik normiran je u čl. 221. st. 3. KZCG-a, za slučaj da su počinjenjem djela "nastupile teške posljedice za izdržavano lice", kada će se počinitelj kazniti zatvorom od šest mjeseci do pet godina. Jednako našem rješenju, počinitelj osnovnog oblika djela neće biti kažnjen ako iz opravdanih razloga nije davao "izdržavanje" (čl. 221. st. 2. KZCG-a). Razlika je uočljiva u normi da "u sudskoj odluci sud određuje obavezu učiniocu da izmiri dospjele obaveze i da uredno daje izdržavanje" (čl. 221. st. 4. KZCG-a). Dakle, kazneni sud obavezno mora u presudi naložiti podmirenje dospjelih obveza uzdržavanja te osuđenika obvezati da ubuduće uredno izvršava obvezu uzdržavanja. Čine to i hrvatski sudovi, ali kroz određivanje posebne obveze. Osuđeniku se nalaže buduće uredno ispunjavanje obveze uzdržavanja i uz stručnu pomoć nadležnog tijela za probaciju. ${ }^{90}$ Odredba čl. 221. st. 4. KZCG-a razlikuje se od odredbe čl. 194. st. 2. KZS-a, gdje je normirano da sud u slučaju izricanja osuđujuće presude "lahko naloži" da ubuduće uredno plaća uzdržavanje te da podmiri zaostatke u plaćanju i druge pripadajuće obveze skopčane s davanjem uzdržavanja. Slovenski sud, prema tome, nema obvezu naložiti buduće uredno izvršavanje obveze uzdržavanje, nego mu je to opcija: može i ne mora tako odrediti osuđujućom presudom.

\footnotetext{
88 Uradni list RS, št. 50/12 - uradno prečiščeno besedilo, 6/16 - popr., 54/15, 38/16, 27/17, 23/20, 91/20 (dalje u tekstu: KZS).

89 "Sl. list RCG", br. 70/2003, 13/2004 - ispr. i 47/2006 i "Sl. list CG", br. 40/2008, 25/2010, 32/2011, 64/2011 - dr. zakon, 40/2013, 56/2013 - ispr., 14/2015, 42/2015, 58/2015 - dr. zakon, 44/2017, 49/2018, 3/2020 (dalje u tekstu: KZCG).

90 ŽsOs broj: Kžzd-73/2019-4 od 6. rujna 2019.; Žs Zg broj: Kžzd-102/18-4 od 3. siječnja 2019.; ŽsŠi broj: Kžzd-23/18-4 od 15. studenoga 2018.
} 


\section{ISTRAŽIVANJE}

Tablica 1.Punoljetne osobe kao počinitelji kaznenog djela povrede dužnosti uzdržavanja prema spolu i radnom statusu tempore criminis te žrtve prema dobi

\begin{tabular}{|c|c|c|c|c|c|c|c|}
\hline \multirow[b]{3}{*}{ 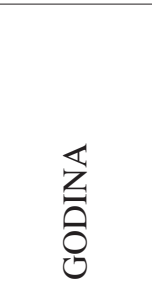 } & \multirow{3}{*}{ 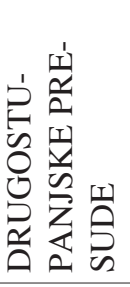 } & \multicolumn{4}{|c|}{ POČINITELJI } & \multicolumn{2}{|c|}{ ŽRTVE } \\
\hline & & \multicolumn{2}{|c|}{ SPOL } & \multicolumn{2}{|c|}{$\begin{array}{l}\text { RADNOPRAVNI } \\
\text { STATUS }\end{array}$} & \multirow[b]{2}{*}{ DJECA } & \multirow{2}{*}{$\begin{array}{c}\text { ODRA- } \\
\text { SLE } \\
\text { OSOBE }\end{array}$} \\
\hline & & M & Ž & $\begin{array}{l}\text { ZAPO- } \\
\text { SLEN }\end{array}$ & $\begin{array}{c}\text { NE- } \\
\text { ZAPO- } \\
\text { SLEN }\end{array}$ & & \\
\hline 2015. & 4 & 4 & 0 & 3 & 1 & 4 & 0 \\
\hline 2016. & 6 & 5 & 1 & 4 & 2 & 6 & 0 \\
\hline 2017. & 9 & 9 & 0 & 8 & 1 & 8 & 1 \\
\hline 2018. & 15 & 15 & 0 & 10 & 5 & 13 & 2 \\
\hline 2019. & 19 & 17 & 2 & 13 & 6 & 18 & 1 \\
\hline $\begin{array}{l}\text { UKUPNO } \\
(\%)\end{array}$ & 53 & $\begin{array}{c}50 \\
(94 \%)\end{array}$ & $\begin{array}{c}3 \\
(6 \%)\end{array}$ & $\begin{array}{c}38 \\
(71,7 \%)\end{array}$ & $\begin{array}{c}15 \\
(28,3 \%)\end{array}$ & $\begin{array}{c}49 \\
(92,45 \%)\end{array}$ & $\begin{array}{c}4 \\
(7,55 \%)\end{array}$ \\
\hline
\end{tabular}

\subsection{Profil punoljetnih počinitelja kaznenog djela i žrtve}

Zaposlenost i sposobnost za rad naročito se izdvajaju kao obilježja počinitelja kaznenog djela povrede dužnosti uzdržavanja. Sudovi osobito vode računa o navedenim značajkama, izdvajaju ih u obrazloženjima sudskih presuda i ističu prilikom osude. Istraživanje je pokazalo da je ogroman broj osuđenih počinitelja bio zaposlen tempore criminis. Očekivano dominiraju osuđenici muškog spola, zbog činjenice da se djeca najčešće povjeravaju na skrb majci. Svega je $6 \%$ osuđenih punoljetnih počinitelja ženskog spola. Kod žrtava, dominiraju djeca i počinitelji kaznenog djela povrede dužnosti uzdržavanja najčešće ostvaruju svojim radnjama obilježja kvalificiranog oblika djela, iz čl. 172. st. 2. u vezi sa st. 1. istoga članka KZ-a. Premda se počiniteljima kaznenog djela iz čl. 172. KZ-a uvijek na teret stavlja i sudi za stjecaj (čl. 51. KZ-a), ovdje nisu posebno izdvojene pojedinačne žrtve, jer su promatrane drugostupanjske presude koje ne sadrže uvijek sve podatke o individualno određenoj žrtvi. Odrasle osobe kao žrtve proučavanog kaznenog djela sudjeluju sa svega 7,55 \% u ukupnom udjelu žrtava. Okolnost da među žrtvama dominiraju djeca, pokazuje izrazitu bezosjećajnost počinitelja, jer riječ je o zakonskoj obvezi koje se roditelj nikako ne može osloboditi i onome što je potrebno učiniti naročito u situaciji kada roditelj ne stanuje s maloljetnim djetetom. 


\subsection{Oblici prekida neprekidnosti radnje djela}

\section{Tablica 2. Načini prekida kontinuiteta radnje kaznenog djela povrede} dužnosti uzdržavanja

\begin{tabular}{|c|c|c|c|}
\hline \multirow{2}{*}{ Svojevoljno } & \multicolumn{2}{|c|}{ KAZNENI POSTUPAK } & \multirow{2}{*}{$\begin{array}{c}\text { Drugi način (ili } \\
\text { nepoznato) }\end{array}$} \\
\cline { 2 - 3 } & $\begin{array}{c}\text { Pokretanje, iniciranje, } \\
\text { vođenje } \ldots\end{array}$ & Pravomoćna osuda & \\
\hline $3(5,66 \%)$ & $14(26,42 \%)$ & $27(50,94 \%)$ & $9(16,98 \%)$ \\
\hline
\end{tabular}

Vrlo rijetko se počinitelji kaznenog djela povrede dužnosti uzdržavanja dobrovoljno opredjeljuju provesti u djelo dužnost na koju su obvezani presudom građanskog parničnog suda u pogledu skrbi o drugoj osobi, najčešće djetetu. ${ }^{91}$ Počinitelj je dužan plaćati obveze uzdržavanja malodobne djece i nauštrb sebe, pa i prodajom svoje pokretne imovine. ${ }^{92}$ Radno sposobni građani, zaposleni ili nezaposleni, moraju pod svaku cijenu pribavljati nužna sredstva za život osoba koje u odnosu na njih imaju pravo na uzdržavanje.

U određenom, manjem broju slučajeva, promatrane drugostupanjske presude ne sadrže točan podatak o obliku prekida kontinuiteta radnje kaznenog djela ili je neodređen, npr. "vjerojatno je ranija pravomoćna presuda zbog istog kaznenog djela počela kod okrivljenice mijenjati njezin stav prema kaznenom djelu povrede dužnosti uzdržavanja." ${ }^{93}$ Stoga su navedene presude prikazane zajedno sa slučajevima kada su osuđenici pogrešno smatrali da postoje drugi razlozi koji ih ekskulpiraju od izvršavanja obveze uzdržavanja utvrđene zasebnom presudom u parničnom postupku. Riječ je o sljedećim primjerima: sastavljanje oporuke u korist oštećenice i nasljeđivanje počiniteljeve njemačke mirovine, uz odricanje suvlasništva na zemljištu ${ }^{94}$ ili prijenos prava vlasništva na suvlasničkom dijelu kuće; ${ }^{95}$ kupovanje odjeće, obuće, školskog pribora i drugih stvari ${ }^{96}$ preuzimanje brige o djeci koja borave kod njega i on ih uzdržava; ${ }^{97}$ punoljetnost žrtve i njeno zapošljavanje ${ }^{98}$ odricanje od dijela zajedničkog obrta. ${ }^{99}$

Kazneni postupak utvrđen je kao poticajna okolnost za izvršavanje obveze dužnog uzdržavanja u $26,42 \%$ slučajeva, primjerice da je okrivljenik počeo plaćati

91 ŽsZg broj: Kžzd-55/17-4 od 22. ožujka 2017.; ŽsVu broj: 1 Kžzd-11/2018-6 od 28. lipnja 2018.; ŽsSt broj: Kžzd-55/2018-2 od 26. lipnja 2018.

92 ŽsVu broj: 2 Kžzd-1/2020-7 od 29. siječnja 2020.

93 ŽsSt broj: Kžzd-73/2018-5 od 4. rujna 2018.

94 ŽsBj broj: Kž-1/2017-4 od 6. srpnja 2017.

95 ŽsŠi broj: Kžzd-23/18-4 od 15. studenog 2018.

96 ŽsVž broj: 5 Kžzd-65/16-5 od 12. prosinca 2017.

97 ŽsSt broj: Kžzd-9/2020-5 od 5. veljače 2020.

98 ŽsSB broj: 21 Kžzd-10/2017-4 od 29. siječnja 2018.

99 ŽsBj broj: Kžzd-31/2019-4 od 14. studenoga 2019. 
uzdržavanje tek nakon prijave $\mathrm{i}$ ispitivanja u kaznenom postupku $\mathrm{u}^{100}$ ili uplate su uslijedile nakon ispitivanja okr. kod policijskog istražitelja, u vezi s predmetnim kaznenim djelom, što upućuje na činjenicu da je okr. ovakvim postupanjem nastojao umanjiti svoju kaznenu odgovornost. ${ }^{101}$ Počinitelji tu nisu čekali pravomoćnost sudske odluke, što je ipak daleko najčešći način prekida kontinuiteta radnje kaznenog djela iz čl. 172. KZ-a. Pogrešno je postupanje odustajanje od kaznenog progona nakon podizanja optužnice jer je optuženik u međuvremenu podmirio "dugovanje" za određeno razdoblje. ${ }^{102}$ Riječ je isključivo o naknadi štete pričinjene kaznenim djelom i ne smije predstavljati osnovu za odustanak od optužbe ili oslobađajuću presudu, odnosno sud navedenu činjenicu može vrednovati kao okolnost bitnu za odmjeravanje kazne. U biti je u tim predmetima vođenje kaznenog postupka ono što je pokrenulo počinitelja na odgovarajuću djelatnost, usmjerenu na izbjegavanje kaznene odgovornosti, premda je djelo već počinjeno.

Pravomoćna osuda, usprkos jednom izdvojenom primjeru, od kojega je isti drugostupanjski sud naknadno reterirao tijekom promatranog razdoblja, predstavlja daleko najčešći praktičan razlog za (privremeni) prestanak neizdvajanja novca ili drugih sredstava za uzdržavanje. Više od polovice $(50,94 \%)$ osuđenika tek je pravomoćna sudska presuda faktično prisilila da prestanu održavati uspostavljeno protupravno stanje i da opet ili prvi put krenu obavljati u potpunosti ono što moraju izvršavati. Budući da ogromna većina nije naknadno uhvaćena u recidivu, nema pouzdanih podataka o zaključcima drugostupanjskih sudova po pitanju eventualnog kršenja načela ne bis in idem.

\section{ZAKLJUČAK}

Počinitelj se mora striktno pridržavati određene obveze uzdržavanja i pritom nije ovlašten samoinicijativno mijenjati naložene uvjete ispunjenja zakonske dužnosti, posebice ne kad je žrtva dijete. Pravomoćna i ovršna odluka po kojoj je netko dužan davati uzdržavanje može se promijeniti samo drugom sudskom odlukom ili nagodbom, ali ne u kaznenom postupku. Radnja trajnog kaznenog djela dovršena je prestankom protupravnog stanja što ga je uspostavio i održavao počinitelj kaznenog djela. Kaznena osuda ne smije predstavljati temelj zaključka da osuđenik nesmetano može nastaviti s neizvršavanjem obveze jer da se radi o trajnom kaznenom djelu. U cijelosti je potvrđena prva hipoteza istraživanja, da su različiti uzroci što dovode do prekida uspostavljenog i po počinitelju održavanog protupravnog stanja. Vremensko trajanje povrede zaštićenog pravnog dobra u slučaju povrede obveze uzdržavanja direktno utječe na visinu štete pričinjene počinjenjem kaznenog djela, dok na strani počinitelja otvara pitanje latentnog kršenja načela ne bis in idem. Različiti su načini prekidanja protupravnog stanja koje nastaje zbog nedavanja uzdržavanja

100 ŽsSt broj: Kžzd-4/2019-5 od 5. veljače 2019.

101 ŽsVu broj: Kžzd-4/2020-6 od 11. svibnja 2020.

102 OsVT broj: 6 K-41/2020-3 od 11. ožujka 2020. 
u praksi. Svojevoljno davanje uzdržavanja, konkretno u vidu plaćanja alimentacije za djecu, upitno je u slučaju kada počinitelj spozna da je protiv njega podnesena kaznena prijava. Nije sigurno što je točno pokretački motiv onoga koji izbjegava dati uzdržavanje, strah od (ishoda) kaznenog postupka ili naglo probuđena svijest o postojećoj obvezi. Naknadno izvršavanje obveze uzdržavanja predstavlja isključivo naknadu štete pričinjene kaznenim djelom i ne smije isključivati odgovornost počinitelja. Uglavnom je potvrđena druga hipoteza istraživanja, da pravomoćna presuda označava prekid protupravnog stanja, osim jednog izdvojenog slučaja kada je drugostupanjski kazneni sud prvo ustvrdio kako je povreda dužnosti uzdržavanja specifično trajno kazneno djelo, gdje osuda sprečava ponovno suđenje. De lege ferenda, treba se prikloniti rješenju iz njemačke doktrine, da pravomoćna sudska presuda kod trajnih kaznenih djela, obligatorno predstavlja vanjski utjecaj koji prekida protupravnu radnju.

\section{LITERATURA}

1. Bačić, Franjo, Krivično pravo, Opći dio, Četvrto, izmijenjeno izdanje, Informator, Zagreb, 1995.

2. Bačić, Franjo, Šeparović, Zvonimir, Krivično pravo: posebni dio, Peto, izmijenjeno i dopunjeno izdanje, Informator, Zagreb, 1997.

3. Bačić, Franjo, Pavlović, Šime, Komentar Kaznenog zakona, Organizator, Zagreb, 2004.

4. Creifelds, Carl, Rechtswörterbuch, 23. Auflage, C. H. Beck, München, 2019.

5. Dragičević Prtenjača, Marta, "Kaznena djela protiv braka, obitelji i djece", u: Cvitanović, Leo, Derenčinović, Davor, Turković, Ksenija, Munivrana Vajda, Maja, Dragičević Prtenjača, Marta, Maršavelski, Aleksandar, Roksandić Vidlička, Sunčana, Kazneno pravo: posebni dio, Pravni fakultet Sveučilišta u Zagrebu, Zagreb, 2018.

6. Horvatić, Željko, Novo hrvatsko kazneno pravo, Organizator, Zagreb, 1997.

7. Horvatić, Željko, Novoselec, Petar, Kazneno pravo (opći dio), Ministarstvo unutarnjih poslova Republike Hrvatske, Policijska akademija, Zagreb, 1999.

8. Horvatić, Željko, Šeparović, Zvonimir, Kazneno pravo (posebni dio), Masmedia, Zagreb, 1999.

9. Horvatić, Željko, Derenčinović, Davor, Cvitanović, Leo, Kazneno pravo, Opći dio 2: kazneno djelo i kaznenopravne sankcije, Pravni fakultet Sveučilišta u Zagrebu, Zagreb, 2017.

10. Novoselec, Petar, Martinović, Igor, Komentar Kaznenog zakona, I. knjiga: opći dio, Narodne novine, Zagreb, 2019.

11. Prokop, Ana, Porodično pravo: usvojenje, Informator, Zagreb, 1970.

12. Roxin, Claus, Strafrecht Allgemeiner Teil, Band I, Grundlagen, Der Aufbau der Verbrechenslehre, 4. Auflage, Verlag C. H. Bech, München, 2006.

13. Singer, Mladen, Mikšaj-Todorović, Ljiljana, Poldrugač, Zdravka, Kriminalitet na štetu maloljetnika, Školska knjiga, Zagreb, 1989. 
14. Turković, Ksenija, Maršavelski, Aleksandar: "Nacrt posebnog dijela novog Kaznenog zakona - pregled pet glava", Hrvatski ljetopis za kazneno pravo i praksu (Zagreb), vol. 17, broj 2/2010, str. 503-551.

\section{TERMINATION OF THE CONTINUITY OF THE PERMANENT CRIMINAL OFFENSE OF VIOLATION MAINTENANCE DUTIES}

The characteristic unlawful condition of intentional avoidance of the obligation to alimony another person, which is created by the perpetrator's activity, can exist depending on or independently of his will. Since the violation of the duty to support is a permanent criminal offense, the question arises whether the final court decision of the criminal court interrupts the continuity of the wrongful and whether it is possible to try the hardened returnee again, without violating the principle of $n e$ bis in idem.

The paper uses a method of analysis, descriptive for the characteristics of the act, and explicit for a special review of the perpetrator's personality and determining the form of temporary cessation of wrongdoing on the part of the perpetrator. The statistical method in combination with the sample method was used to conduct a specific survey of characteristic cases on a systematic sample of adult perpetrators of the criminal offense in the territory of the Republic of Croatia.

The results of the research show that the end of the action of denying the allocation of funds for the alimony doesn't always depend on perpetrator's actions, that the conviction shouldn't be a ground or stimulant for further breach of obligation and that a final court judgment must be the basis for the conclusion that the perpetration of a permanent criminal offense of breach of the duty of maintenance has been completed.

In conclusion, it's established that a conviction for a permanent criminal offense of violation of the duty of maintenance doesn't include further maintenance of an unlawful situation caused by failure to comply with the legal obligation of the perpetrator to obtain alimony.

Key words: right to maintenance, violation of the duty of maintenance, permanent criminal offense, action, illegal situation 